\title{
Value-laden issues and English as a Second/Foreign language teaching in secondary education: A perfect combination enabled through ICT
}

\author{
Diego Rascón-Moreno ${ }^{1}$
}

The English as a Foreign/Second Language teacher has the opportunity of making classes quite beneficial because they can address essential topics for students at the same time as they teach the most global language at the moment. Especially now, they can make this combination in a relatively easy way through the use of a variety of ICT applications. This paper describes four projects carried out in two Spanish secondary schools. On the basis of their statisticallyfounded results, it can be concluded that teaching value-laden issues is perfectly viable within the compulsory secondary education English classroom by means of computer technology. [Article copies available for a fee from The Transformative Studies Institute. E-mail address:_journal@transformativestudies.org_Website: http://www.transformativestudies.org (02014 by The Transformative Studies Institute. All rights reserved.]

KEYWORDS: Values Education, Foreign Language, ESL, Secondary Education, Information and Communication Technology (ICT).

\section{INTRODUCTION}

The teacher of English as a Second/Foreign Language has the potential to be a very important educator and relevant figure in society. This potential is based on her/his being the one that can more easily integrate

\footnotetext{
${ }^{1}$ Diego Rascón-Moreno, Ph.D., is a teacher of English at the Modern Language School of the University of Jaén (Spain) where he received his Doctorate in English linguistics, literature and teaching in 2011. His research interests are the primary and secondary education English classrooms, values education, global issues teaching, computerassisted language learning (CALL) and European Higher Education. His recent published work includes Developing Global Citizenship Competence in English Studies (LINCOM, 2012), Global Issues in Language, Literature and Linguistics Teaching (Peter Lang, 2013) and Teaching by Doing: A Professional and Personal Life (Universidad de Jaén, 2013). Address correspondence to: Diego Rascón-Moreno, Avenida de Madrid 66, 7H, Escalera 4a , 23008, Jaén, Spain; e-mail: drascon@ujaen.es.
} 